\title{
Sustainable viticulture and winery practices in California: What is it, and do customers care?
}

\author{
This article was published in the following Dove Press journal: \\ International Journal of Wine Research \\ 16 June 2009 \\ Number of times this article has been viewed
}

\section{Gary Zucca ${ }^{1,2}$ \\ David E Smith ${ }^{3,4}$ \\ Darryl J Mitry ${ }^{5,6}$}

'National University, Stockton, CA, USA; ${ }^{2}$ Owner and Winemaker, Zucca Mountain Vineyards, Vallecito, CA, USA ${ }^{3}$ National University, Costa Mesa, CA, USA; ${ }^{4}$ Copenhagen Business School, Copenhagen, Denmark; ${ }^{5}$ Graduate School Faculty, Norwich University, Northfield, VT, USA; ${ }^{6}$ National University, San Diego, CA, USA
Correspondence: David E Smith Professor, National University, 3390 Harbor Blvd, Costa Mesa, California 92626, USA

Tel +I 9497866361

Fax + I 9497863642

Email dsmith8@nu.edu
Abstract: Producers in the wine industry are increasingly competing in the area of product differentiation. The focus of this article is product differentiation via sustainable viticulture and consumer perception. The authors report on their independent research, assess previous findings in the literature, and examine the industry trends. The study concludes with important observations on wine consumer perceptions of sustainable practices in the wine industry and implications for industry practices and product development.

Keywords: California, biologique, organic, biodynamic, sustainable

\section{Background}

Over the past dozen years, words such as green, organic, biodynamic, and biologique became popular terms to characterize vineyards and wineries from California to Bordeaux and Tuscany. These terms refer to growers and winemakers that have begun paying increasing attention to the impact of their practices on the environment. ${ }^{1-5}$ In California, the term "sustainable agriculture" emerged as a more descriptive and acceptable term for environmentally friendly practices in the wine industry. ${ }^{6}$

Environmental practices have become particularly important in California. After the Second World War, agricultural land was increasingly turned into sprawling residential and commercial developments. Understandably, there has been growing tension between large-scale industrial practices that are reluctant to change and the urban sprawl, which has taken over much of the prime farm land. Agricultural practices such as burning, flood irrigation, pesticide spraying, groundwater and air contamination, as well as other social, economic, and environmental problems have resulted in government interventions and increased regulation. These policies and the commercial tensions have become an increasing burden on an already languishing agriculture industry.

Partly in reaction to increasing government regulation and partly due to an increased awareness of the agriculture industry's social and environmental responsibility, there has been movement toward more sustainable agriculture practices. Sustainable agriculture is characterized by a systems perspective of stewardship of the natural and human resources; it comprises three goals: environmental health, economic profitability, as well as social and economic equity. Achieving sustainable agricultural practices is viewed as a process requiring small, realistic, and measurable steps. 


\section{Sustainable wine production in California}

The concept of sustainable winegrowing and winery practices in California began in the early 1990s and developed principally from the efforts of growers and winemakers in the central valley of California around the town of Lodi. ${ }^{3}$ In 1995, the Lodi-Woodbridge Winegrape Commission ${ }^{7}$ began to establish demonstration vineyards where a range of sustainable winegrowing practices were implemented and tracked over time. In 2002, the Lodi-Woodbridge Winegrape Commission published the Lodi Winegrower's Workbook: A self-assessment of integrated farming practices. ${ }^{8}$ The purpose of the Lodi Winegrower's Workbook was to increase sustainable winegrowing practices by Lodi growers, and to establish benchmarks of practices that could be tracked over time. According to Chris Ohmart, the Director of Sustainable Winegrowing for the Lodi-Winegrape Commission, the workbook and implementation program were the first of their kind to apply the environmental management systems model to winegrapes. ${ }^{8,9}$ The workbook practices have since influenced wine industries in states beyond California and the sustainability practices have begun to be adapted for use in other countries.

The sustainable winegrowing program developed in Lodi has been adapted by several other regional winegrowing associations and regions in California. It was also used as a model to develop a state-wide program by the principal wine industry associations in California, the Wine Institute, representing the wineries, and California Association of Winegrape Growers (CAWG), representing the winegrape growers.

The Wine Institute is an association of almost 1,000 California wineries and affiliated businesses whose members account for $95 \%$ of California wine production and $85 \%$ of wine production in the United States. Established in 1934, the organization is dedicated to initiating and advocating state, federal, and international public policy to enhance the environment for the responsible consumption and enjoyment of wine. The Wine Institute seeks to broaden public understanding of the wine industry and its role in the American economy, lifestyle, and culture. Based in San Francisco with offices in Sacramento, Washington, DC, and six regions across the United States and with representatives in all states and 10 foreign countries, the Wine Institute is the oldest public policy organization representing wine in the United States. ${ }^{10}$

The California Association of Winegrape Growers (CAWG) represents California winegrape growers and provides industry leadership to advocate public policies, research and education programs, sustainable practices, and trade positions to improve the viability of winegrapes. CAWG's membership represents the growers of approximately $60 \%$ of the total annual grape crush. ${ }^{11}$

In 2001, the Wine Institute and CAWG formed the California Sustainable Winegrowing Alliance (CSWA) and developed the Code of Sustainable Winegrowing Practices Workbook as the basis for the Sustainable Winegrowing Program, providing a tool for vintners and growers to assess their practices and learn how to improve their overall sustainability. The vision of the Sustainable Winegrowing Program is the long-term sustainability of the California wine community. To place the concept of sustainability into the context of winegrowing, the program defines sustainable winegrowing as growing and winemaking practices that are sensitive to the environment (environmentally sound), responsive to the needs and interests of society-at-large (socially equitable), and are economically feasible to implement and maintain (economically feasible). The combination of these three principles is often referred to as the three "E's" of sustainability, as in Figure 1.

The Code of Sustainable Winegrowing Practices Self-Assessment Workbook is the foundation of the Sustainable Winegrowing Program and a tool for program participants to measure their level of sustainability and to learn about ways to improve their practices. The workbook describes ways to translate the above three broad principles into practice and provides growers and winemakers a self-assessment guide to improve their practices. Originally released in 2002, a second edition of the workbook was issued in 2006. The workbook addresses ecological, economic, and social equity criteria through an integrated set of 14 chapters and 227 criteria,

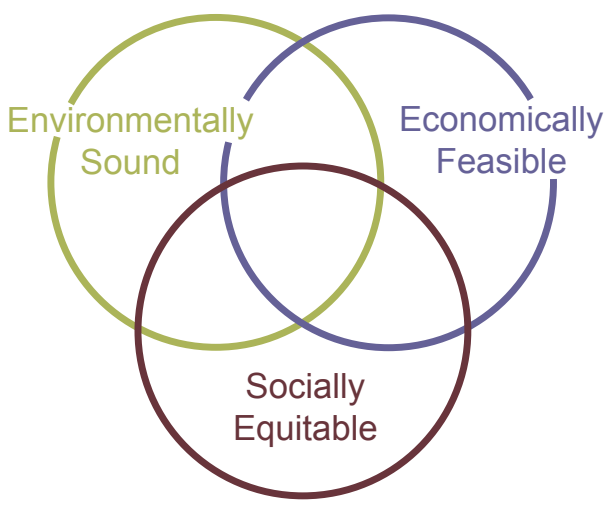

Figure I Sustainability is defined by the three overlapping principles of environmentally sound, economically feasible and socially equitable. Copyright (C) 2006. Reproduced with permission from the California Sustainable Winegrowing Alliance. 
which includes a built-in system with metrics to measure performance. The 14 assessment areas are:

1. Viticulture.

2. Soil management.

3. Vineyard water management.

4. Pest management.

5. Wine quality.

6. Ecosystem management.

7. Energy efficiency.

8 . Winery water conservation and quality.

9. Material handling.

10. Solid waste reduction and management.

11. Environmentally preferred purchasing.

12. Human resources.

13. Neighbors and community.

14. Air quality.

For each of the 14 areas the workbook describes four categories in order of increasing sustainability, and each category has specific measures to assess the current state of the vineyard or winery. The workbook also provides a worksheet to assess the current status in all 14 areas and to develop an action plan to improve in each area. The CSWA workbook is not meant to be a "how-to manual," nor set of rules, or a rating system used by external evaluators to judge vineyard or winery operations, and is not linked to any certification system. However, because of interest expressed by members, the workbook is designed to be easily adapted to international environmental management system standards such as the ISO 14000 family and international sustainability reporting efforts such as the Global Reporting Initiative. ${ }^{10,11}$

\section{Implementation and current status of sustainable winegrowing practices}

The sustainable winegrowing program is designed to engender a cycle of continuous improvement among growers and vintners, by enabling them to evaluate their own operations, learn about new approaches and innovations, and increase their adoption of sustainable practices. The program cycle consists of: a) providing participants with a practical self-assessment workshops based on the workbook; b) tracking and measuring the results of self-assessments; c) offering important information and educational opportunities about sustainable practices, focused on areas needing improvement; d) facilitating exchange of information among growers and vintners; and e) motivating participants to implement effective changes. Participants are encouraged to re-assess themselves and, to continue this cyclical process of evaluation, learning, and improvement.

The CSWA presented its first report measuring the level of sustainable practices among vintners and growers on a statewide basis on October 6, 2004. The report is the first time the entire agriculture industry sector in California has used a common assessment tool to document the adoption of sustainable practices among its members and reported the results publicly. The evaluation results collected from over 70 workshops are contained in the 2004 report, and represent about $40 \%$ of the California's 260 million case production and $25 \%$ of its 529,000 wine acres. ${ }^{12}$ By 2006 , participation had increased to $32.9 \%$, comprising 1,165 California wineries and vineyards involved in the self-assessment process on the slightly reduced acreage of $522,000 .{ }^{13}$ A summary of vineyard and winery participation in the program as of October 2006 is illustrated in Table 1.

As shown in Table 1, the majority of wineries in California have participated in the program, although the program seems to be supported mainly by the larger growers who have the resources to pursue and document sustainable efforts. Based on the survey interviews with growers and winemakers the anecdotal evidence supports the probability that many of the small growers and winemakers are also pursuing the program, but they are not documenting and reporting the results.

\section{Future trends of sustainable winegrowing practices}

Training goals for introducing the sustainable winegrowing program to other growers and winemakers continues. From July 2007 to June 2008, there were 23 seminars in self-assessment scheduled. ${ }^{12}$ The program also recently started a website, which includes a web-based self-assessment and reporting system. In addition to offering participants the option to complete and submit their self-assessments on-line, the new system allows vintners and growers the ability to generate their own customized sustainability reports, to link to other web-based resources, and to develop and save action plans for improving practices. ${ }^{12}$

There is clear evidence that the sustainable winegrowing program is being accepted by large growers and winemakers, and that the number of growers and winemakers using the workbook to evaluate their operations is growing. There is less solid evidence that smaller growers and winemakers are aware and are using the handbook, but anecdotal evidence seems to indicate that most are aware of the program and are actually using the workbook to evaluate their operations. 
Table I Vineyard and winery self-assessments as of October 2006. Data sourced from the Winegrowing Progress Report (2006) by the California Sustainable Winegrowing Alliance

\begin{tabular}{|c|c|c|}
\hline \multicolumn{3}{|l|}{ Vineyard self-assessment } \\
\hline Number of distinct vineyards & 990 vineyards & Percentages \\
\hline Total vineyard acres farmed by the 990 enterprises & 288,072 acres & $55.2 \%$ of 522,000 total statewide acres \\
\hline Number of vineyard acres assessed by the 990 vineyards & I7I,764 acres & $32.9 \%$ of 522,000 total statewide acres \\
\hline Number of vineyards that submitted assessment results & 807 vineyards & $81.5 \%$ of 990 total enterprises \\
\hline Total vineyard acres from the 990 vineyards & I52,799 acres & $29.3 \%$ of 522,000 total statewide acres \\
\hline \multicolumn{3}{|l|}{ Winery self-assessment } \\
\hline Number of distinct wineries & 175 wineries & Percent \\
\hline Total cases produced by the 175 wineries & I 70.7 million cases & $62.5 \%$ of 273 million total statewide cases \\
\hline Number of cases assessed by the 175 Wineries & | 43.8 million cases & $52.7 \%$ of 273 million total statewide cases \\
\hline Number of wineries that submitted assessment results & 107 wineries & $61.1 \%$ of 175 total facilities \\
\hline Total cases from the 107 wineries assessed and submitted & I |4.9 million cases & $42 \%$ of 273 million total statewide cases \\
\hline
\end{tabular}

The online self-assessment reporting system may provide better evidence of small grower and winemaker support as it makes it much easily for small producers to participate in reporting.

The current sustainable winegrowing program relies on self assessment and self-reported data. Based on the research in this report the authors believe that the wine industry will soon develop a certification program for sustainable winegrowing and winemaking. Evidence of this trend is emerging even now. The Lodi-Woodbridge Winegrape Commission, representing a California wine appellation, has developed California's first sustainable winegrowing standard whereby participating growers have their vineyards certified as producing winegrapes sustainably. The certification is done by a third party, which means the standards have been reviewed and endorsed by an organization independent of the Lodi-Woodbridge Winegrape Commission. The association provides certified vineyards a logo that can be attached to products from that vineyard certifying that they are produced from certified sustainable vineyards. ${ }^{7}$ In the next few years the authors of this article predict that the wine industry will have a certification program much like the current organic agriculture program now in place with the United States Department of Agriculture. ${ }^{14}$

Although the concept of sustainability in viticulture is not new, the concept is of growing interest. ${ }^{15}$ Through the Code of Sustainable Winegrowing Practices, the process of sustainable winegrowing practices is being implemented in California. There are a number of current issues involved in implementing the Code and the future of sustainable winegrowing practices in California.
Research on customer awareness of sustainable agriculture is valuable information for addressing some of these issues and for purposes of forecasting future trends. The authors' research on consumer awareness illustrates that consumers are confused by the different terms used to describe sustainable viticulture and wine making. Such terms such as organic, biodynamic, low carbon footprint, and sustainable agriculture derive from different stages in agricultural production, but some are beginning to grasp the concept of sustainability. ${ }^{16}$ There has been too little research on customer awareness of sustainable viticulture and winemaking and less on whether customers truly value these practices and will be willing to patronize a winery that follows sustainable practices over ones that do not. ${ }^{17}$ The results of the study reported here will help answer the question of consumer response to these sustainable practices in wine production

\section{Methodology and findings of consumer awareness study}

Data for this study were gathered from a large number of structured personal interviews. A series of questions was used to determine the consumers familiarity with the terminology used to refer to sustainable viticulture and wine production. Follow up questions were focused on the degree of understanding of such sustainable practices, and the effects on product development. Therefore, the questions were prearranged in order to avoid prompting of information, so that the answers given would be without investigator bias. While the questions were methodically screened and the investigators intension is structured, the setting of these interviews was informal. The usual constraints of interviewing customers while they are wine tasting did not 
permit gathering a probability sample in strictly statistical terms. Therefore, parametric analysis is not forced on the sample survey; nonetheless, the authors consider that the sample is sufficiently representative and valid to be able to be compared to the research conducted on wine consumers in other locations.

A total of 300 wine-buying customers, members of wineindustry associations, and various winegrowers and winemakers were subjected to the structured interview process. The structured process addressed the potential problem of "leading the respondent." To avoid this potential problem, the interviewer followed a script that ordered questions so as to eliminate any possibility of influencing the respondent or introducing unfamiliar words that identify sustainable practices. These personal interviews were conducted at three wineries in Murphys, California, considered a representative area in the wine country of the Sierra foothills. The study was conducted to determine both relative level of customer awareness and the value placed by wine customers on sustainable practices for production of wine.

The research results in a reasonable assessment of the state of sustainable viticulture and winemaking in California and provides recommendations for developments in the future. The implications of this research can also be useful to individuals involved in implementing the Code of Sustainable Winegrowing Practices in California and to wineries and other winegrowers who are interested in following and promoting sustainable agricultural practices to their customers.

\section{Findings}

Research on consumer awareness and acceptance of sustainable winegrowing practices was conducted by the aforementioned interviews of wine customers at California wineries, and assessed in light of the literature on the subject. ${ }^{7,17}$ The results of the survey interviews can be summarized as follows: Customers like the concept of sustainable winemaking (overwhelming majority responded positively) but they really do not have a clear idea what sustainability means in practice or what processes the wineries do to achieve it. Specifically:

- $52 \%$ of respondents were familiar with the term "sustainability."

- $10 \%$ indicated they knew of one or more companies that supported sustainable values.

- $90 \%$ thought that sustainable practices were an important feature of wine production and would buy the products from such vineyards.
- Only $7 \%$ were able to identify specific aspects of sustainable practices.

These findings are supported by the literature that serves to indicate validity the findings of this research. For example, the previous Hartman Group study (2007) found that sustainability is an evolving concept that consumers associate with six key values: healthier, local, social responsibility, environmental responsibility, simple living, and control. The Hartman study was based on 150 hours of interviews in six cities and a survey of 1,600 individuals in a nationally-representative sample in the United States. The study found the following:

- Just over half (54\%) were familiar with the term, "sustainability".

- Only 5\% indicated they knew companies that supported sustainability values.

As a marketing term, sustainability is not a household word, but consumers are willing to pay a premium for products that are produced with environmentally friendly sustainable processes. ${ }^{17}$

The results of this California study complement the previous research and further support the finding that consumers are interested in purchasing these products. Moreover, ceterius paribus, wine consumers are showing the potential for preference toward wine products produced under sustainable practices. This is an important finding. The majority of responses indicate a willingness to pay a premium for the products identified as produced with sustainable viticulture practices. Therefore, the remaining issue is developing appropriate programs that help the consumer identify and distinguish these products.

\section{Conclusions}

Sustainable winegrowing and winemaking is a term already accepted by a large number of winegrowers and winemakers and will continue to become even more widely accepted in the professional community. Currently sustainability is a voluntary program but it is expected to evolve into a program that will be certified by various associations in the wine industry. Whether the certification will require third-party verification is still unclear, but the trend seems to be going in that direction.

The concept of sustainability originated with winegrowers and local and regional wine associations. Thus far, the wine industry is doing its own self assessment and therefore the many government regulatory agencies have not become involved. Clearly, sustainability in the wine industry is going to continue to grow in the future. If it is to remain a viable 
and useful concept, it must remain a local program and be modified to meet local needs. Implementing sustainability programs in new areas should be done in cooperation with local associations and local officials such as county farm advisors and agricultural agents.

Currently consumer awareness of sustainable winegrowing and winemaking is low and product and processes are confused with vague terms such as organic and green, but as consumer awareness grows, the market will see growing acceptance and demand for wine produced from sustainably farmed grapes and made in certified sustainable wineries. The industry will need to cooperatively develop and support appropriate marketing programs that help the consumer identify and distinguish these products from others. The aforementioned example of the Lodi Association providing certified vineyards a logo that can be attached to products certifying that they are produced from a certified sustainable vineyard is a step toward making product identification more easily available to consumers. Effective programs will result in increasing demand for wine products produced under sustainable viticulture. The potential for this market segment appears to be significant and viable. The research supports recommendations for industry investment in efforts to inform the potential wine customers and make it easier for them to identify the products produced with these environmentally friendly and sustainable practices.

\section{Disclosure}

The authors report no conflicts of interest in this work.

\section{References}

1. Hall SL. Is viticulture getting enough attention in Bordeaux? Wine Business Monthly. Dec 1, 2001. [cited 2008 Mar 11]. Available from: http://www.winebusiness.com/wbm/?go=getArticle\&dataId=16093.

2. Rosen M. New Italian prize for sustainable viticulture. Decanter. Nov 17, 2006. [cited 2008 Mar 11]. Available from: http://www.decanter.com/ news/101021.html.
3. Warner K. The quality of sustainability: Agro ecological partnerships and the geographic branding of California winegrapes. J Rural Stud. 2007:23(2):142-155.

4. Bentley W. Biologically integrated farming systems for table grapes extended. University of California Sustainable Agriculture Research and Education Program. Sustainable Agriculture. 2008;20(1):6-7. [cited 2008 Mar 11]. Available from: http://www.sarep.ucdavis.edu/newsltr/ v20n1/v20n1.pdf.

5. European Commission, Agriculture and Rural Department. Agriculture and the environment: Introduction. 2008. [cited 2008 Jan 23]. Available from: http://www.ec.europa.eu/agriculture/envir/index_en.htm.

6. Feenstra G, Ingels C, Campbell D. What is sustainable agriculture? University of California Sustainable Agriculture Research and Education Program. Dec 1997. [cited 2008 Mar 13]. Available from http://www.sarep.ucdavis.edu/Concept.htm.

7. Lodi-Woodbridge Winegrape Commission. The Lodi rules for sustainable winegrowing. 2002. [cited 2008 May1]. Available from: http://www.lodiwine.com/lodirules_home1.shtml.

8. Ohmart C. Innovative outreach increases adoption of sustainable winegrowing practices in Lodi region. California Agriculture. 2008;62(4):142-147. Available from: http://repositories.cdlib.org/cgi/ viewcontent.cgi? article $=3204 \&$ context=anrcs $/$ californiaagriculture.

9. Martin R. ISO 14000/ISO 14001 Environmental Management Guide. National Center for Environmental Decision Making Tech. Rep. NCDER/98-06. 2007. [cited 2008 May1]. Available from: http://www. iso14000-iso14001-environmental-management.com/.

10. Wine Institute. Welcome to the Wine institute. 2008. [cited 2008 May 1]. Available from: http://www.wineinstitute.org/.

11. California Association of Winegrape Growers (CAWG). 2008. [cited 2008 May 2]. Available from: http://www.cawg.org/.

12. California Sustainable Winegrowing Alliance (CSWA). Sustainability reports. 2008. [cited 2008 May 2]. Available from: http://www. sustainablewinegrowing.org/sustainabilityreports.php.

13. California Sustainable Winegrowing Alliance (CSWA). The code of sustainable winegrowing practices: Self-assessment workbook. 2006. [cited 2008 Feb 21]. Available from: http://www. sustainablewinegrowing.org/swpworkbook.php.

14. United States Department of Agriculture (USDA). Organic certification. 2008. [cited 2008 May 1]. Available from: http://www.usda.gov/wps/ portal/!ut/p/_s.7_0_A/7_0_1OB?navid=ORGANIC_CERTIFICATIO $\&$ parentnav $=$ AGRICULTURE\&navtype $=$ RT .

15. Caputo T. Consumers begin to grasp 'sustainability.' Wines \& Vines. October 15, 2007. [cited 2007 Oct 15]. Available from: http://www. winesandvines.com/template. $\mathrm{cfm}$ ? section=news\&content $=50866$.

16. Anson J. Sustainable viticulture: So vague it's meaningless. Decanter. Sept 26, 2007. [cited 2008 Mar 11]. Available from http://www. decanter.com/news/101021.html.

17. The Hartman Group. Sustainability from a consumer perspective. Study report to the Sustainable Ag. Expo. 2007. [cited 2007 Nov 2]. Available from http://www.hartman-group.com/.
International Journal of Wine Research

\section{Publish your work in this journal}

The International Journal of Wine Research is an international, peer-reviewed open-access, online journal focusing on all scientific aspects of wine, including: vine growing; wine elaboration; human interaction with wine; and health aspects of wine. The journal provides an open access platform for the reporting

\section{Dovepress}

of evidence based studies on these topics. The manuscript management system is completely online and includes a very quick and fair peer-review system, which is all easy to use. Visit http://www.dovepress.com/testimonials.php to read real quotes from some of our published authors. 